$0 \cdot 3 \mathrm{~N}$ of free sulphuric acid. They observed thirdorder kinetics :

$$
\text { Rate } \infty \text { [amine] }\left[\mathrm{HNO}_{2}\right]^{2} \text {. }
$$

They seem to have been unaware of the earlier work, and to have assumed that their equation would apply at the lower acidities (a misconception which appears in several modern text-books). Equation (2) is identical with T. W. J. Taylor's equation for the action of nitrous acid on aliphatic primary and secondary amines ${ }^{5}$. This is satisfactory, since Austin has shown ${ }^{8}$ that the deamination of aliphatic primary amines almost certainly proceeds through a diazonium compound : all these reactions depend on N-nitrosation.

As to the interpretation of the third-order equation (2), two main suggestions have been made. One, due to Kenner, assumes ${ }^{7}$ that the second nitrous acid molecule is required to supply a nitrite ion, which is needed in order to extract a proton from the reaction complex. This has been disproved by Austin ${ }^{6}$, who has shown that other anions, comparable in basic strength to the nitrite ion, have no effect on the reaction. The other suggestion, due to Hammett ${ }^{8}$, recognizes that the third-order kinetics of equation (2) would agree with a rate-determining attack by $\mathrm{N}_{2} \mathrm{O}_{3}$. However, there can be no settled conclusion so long as the second-order kinetics applying to the lower acidities cannot be accommodated: hitherto this difficulty has been ignored.

Consistently with the results of the earlier workers, we have found that, in the aqueous diazotization of aniline in the presence of perchloric acid, the overall reaction-order does indeed drop, substantially from 3 at acidities above $0.05 \mathrm{~N}$, to 2 at acidities below $0.002 N$. But we have also found that the order 2 does not consist, as those investigators assumed without proof, of an order of 1 with respect to each reagent; it consists of the order 0 with respect to the amine, and the order 2 with respect to nitrous acid. The true equation for low acidities is as follows :

$$
\text { Rate } \infty\left[\mathrm{HNO}_{2}\right]^{2} \text {. }
$$

This key result may be illustrated. One way of demonstrating a zeroth-order reaction with respect to the amine involves keeping the concentration of nitrous acid constant. We have to remember that, in equations (2) and (3), "amine" means the free base, and " $\mathrm{HNO}_{2}$ " means the non-ionized acid. We can keep the concentration of non-ionized nitrous acid constant by having the stoichiometric nitrous acid in large excess, and then buffering with respect to $p H$. This last proceeding maintains the nonionized nitrous acid as a constant fraction of the stoichiometric nitrous acid; it also renders the free amine a constant fraction of the stoichiometric amine. Some linear reaction - time curves, illustrating zerothorder diazotization under these conditions, are shown in Figs. 1 and 2. Evidently the rates are in. dependent of the concentration of the amines, in the region of acidity illustrated; and they are independent of the nature of the amines over the range shown. From the dependence of rate on the stoichiometric concentration of nitrous acid and on $p \mathrm{H}$, it is easily deduced that the order with respect to molecular nitrous acid is 2 .

The conclusion is obvious (see table on p. 642). Equations (3) and (2) jointly establish $\mathrm{N}_{2} \mathrm{O}_{3}$ as the nitrosating agent. At quite low acidities, the concentrations of free amine are large enough to secure that the $\mathrm{N}_{2} \mathrm{O}_{3}$ shall be destroyed as fast as it is formed. Thus the zeroth-order rates are those of the formation of $\mathrm{N}_{2} \mathrm{O}_{3}$ from nitrous acid. At the higher acidities, there is so little free amine that the $\mathrm{N}_{2} \mathrm{O}_{3}$ is able closely to approach its equilibrium concentration. The evidence is entirely parallel to that adduced by Hughes, Ingold and Reed ${ }^{9}$ for nitration by $\mathrm{NO}_{2}{ }^{+}$, and by De la Mare, Hughes and Vernon ${ }^{10}$ for chlorination by $\mathrm{Cl}+$.

Equation (3) alone might have suggested nitrosation by $\mathrm{NO}^{+}$, formed through $\mathrm{N}_{2} \mathrm{O}_{3}$; but the changeover to equation (2) at the higher acidities excludes this interpretation: nitrosation in our conditions is by non-ionized $\mathrm{N}_{2} \mathrm{O}_{3}$. On the other hand, at really high acidities, we may expect to observe nitrosation by $\mathrm{NO}^{+}$or $\mathrm{H}_{2} \mathrm{NO}_{2}^{+}$: a report relating to such media will be offered later.

[May 5.

${ }^{1}$ Ber., 32,1691 (1899).

2 Bull. Soc. chim., 27, 19 (1920).

3Proc. Acad. Sci. Amsterdam, 23, 249 (1920).

- Ber., 70, 421 (1937).

s J. Chem. Soc., 1099, 1897 (1928); 2052 (1929).

- Thesis, Univ. London (1950).

${ }^{7} J$. Chem. Soc., 838 (1934); Chem. and Indust., 60, 443, 899 (1941).

8 "Physical Organic Chemistry" (McGraw-Hill, 1940).

- Nature, 158, 448 (1946).

io Research, 3, 192, 242 (1950).

\section{TENTH INTERNATIONAL ORNITHOLOGICAL CONGRESS}

$\Delta \mathrm{T}$ the first International Ornithological Congress, $A$ held in Vienna in 1884 , it was reported that "it was attended by representatives of almost all civilized countries, except England and America, ornithologists even coming from such distant lands as Brazil, Hawaii and Siam". At the Tenth International Ornithological Congress, held sixty-six years later in Uppsala in June last under the presidency of Dr. Alexander Wetmore (United States), there were seventy-nine members from the British Isles and thirty-three from the United States of America. Though Brazil, Japan and Hawaii and Siam were not represented, ornithologists from such far distant countries as Venezuela, New Zealand and India were present.

As this was the first Congress since the War, the last having been held in Rouen in 1938, it speaks much for the ability of the organising secretary, Prof. Sven Horstadius, of the Zoologiska Institutionen, Uppsala, and president of the Svenska Ornitologiska Förening, that he was able to bring together 370 ornithologists from twenty-seven different countries. Meeting in a neutral country in the pursuit of a common interest, the bitterness of recent years was obliterated, as was evidenced by the large representation from Germany, a country which has always been to the forefront in the science of ornithology, and the fact that Russian ornithologists sent a long telegram of good wishes and regrets that their own ornithological meetings prevented their participation.

The programme of papers read at the Congress showed the change in aspect of the approach to the study of birds, for while at the beginning of the century emphasis was on systematics and taxonomy, the modern trend is towards the study of migration, behaviour, ecology and population dynamics.

Though the president chose palæontology as the subject of his opening address, "Recent Additions to 
our Knowledge of Prehistoric Birds", there were only two other papers on this subject, "Moa Deposits on Pyramid Valley Swamp, New Zealand", by Dr. R. Murphy (United States), and "Eine Rekonstruktion des Schädels des Archoeornis siemensi Dames" (with demonstration), by Dr. A. Kleinschmidt (Germany). Dr. E. Sutter (Switzerland) on "Wachstum und Differenzierung des Gehirns bei Nestflüchtern und Nesthockern" was the sole contributor on bird anatomy.

There was a larger number of papers on systematics and evolution, including "Der Einfluss philosophischer Naturbetrachtung auf die ornithologische System. atik" by Prof. Erwin Stresemann (Germany), "Bird Speciation" by Dr. Ernst Mayr (United States), "Systématique des Turdidés" by J. Dorst (France), "On some Phylogenetic Trends in Garrulus glandarius and Dendrocopus major" by Dr. J. M. Harrison (Great Britain), "Races of the Bean Goose (Anser fabalis) in Western Europe" by R. A. H. Coombes (Great Britain), and "Nomenclature, Genetics and Classification in Guinea Fowls" by Prof. A. Ghigi (Italy).

Bird migration and orientation were the subjects of no less than twenty papers, including a general review of bird migration by Prof. Rudolf Drost, director of the Vogelwarte, Heligoland. The Section on Population Dynamies, which opened with a paper on "Population Ecology" by Dr. David Lack, had fourteen other papers, ranging from "Control of the Herring Gull and the Cormorant on the New England Coast" by Dr. A. O. Gross (United States) to "Census of Swedish Rookeries" by T. Malmberg (Sweden).

Dr. N. Tinbergen (Holland) opened the Section on Bird Behaviour with a report on recent advances in this subject, and was followed by six papers, three of which were illustrated with films.

An innovation was a full-day round-table conference on bird ringing presided over jointly by Dr. A. Landsborough Thomson (Great Britain) and F. C. Lincoln (United States). The quality and types of rings, methods of presenting reports of recoveries, and closer collaboration between ringing organisations were among the points discussed, and a permanent committee was set up to facilitate the exchange of ideas.

At the opening meeting of the Congress an intro. duction to Swedish ornithology was given by Prof. Sven Horstadius, and colour films of Swedish wild life were shown by Bertil Haglund.

Every evening, films on various aspects of ornith. ology were shown, those of the most outstanding interest being one of the rediscovered Takake (Notornis) by Dr. R. A. Falla (New Zealand), which was shown on his behalf by R. B. Sibson, and Prof. A. A. Allen's colour film of the bristle-thighed curlew.

During the Congress various excursions were made, one by boat to the archipelago off Norrtalje, and another, starting at midnight, to the forests of Uppland. Linnæus's house at Hammarby, and old Uppsala, were also visited. A final banquet, given by the Svenska Ornitologiska Förening in the Great Hall of the Vasa Castle, presided over by the Governor of the Province of Uppsala, Mr. H. Kjellman, followed by Swedish student songs and folk dances performed by the students of the University, was an occasion of unique charm and impressiveness that will never be forgotten by the many foreigners present.
Both before and following the Congress, most efficiently organised field excursions were made to various parts of Sweden, some members going to Kiruna and Abisko in Lapland, others to the mountains and lakes of Jamtland, and to Narke and Varmland in the lake district of central Sweden, while yet others visited the islands of Göttland and Oland. The recently established ringing station at Ottenby on the island of Oland showed the great work being done in this direction by Swedish ornithologists.

The Eleventh International Ornithological Congress will be held in Switzerland in 1954, under the presidency of Dr. A. Landsborough Thomson, who is president of the British Omithologists' Union.

\section{CHESS-PLAYING MACHINES}

A $\mathrm{N}$ article entitled "Programming a Computer for A Playing Chess", by Dr. C. E. Shannon, of the Bell Telephone Laboratories, which appears in the March issue of the Philosophical Magazine $(41,256$; 1950) will doubtless interest many chess players as well as those concerned with electronic computing. The paper was originally presented at the National I.R.E. Convention in New York in March 1949 and deals with the theoretical problem of constructing a computing routine or 'programme' for a modern general-purpose computing machine. Dr. Shannon himself was one of the contributors to the recent symposium on information theory held in London during September 26-29.

It will. be recalled that in recent years Dr. D. W. Davies, of the National Physical Laboratory, built an electro-mechanical machine for playing the game of noughts-and-crosses ${ }^{1}$, and this machine was exhibited at the Royal Society conversaziones of 1949. But though machines for chess and noughts-and-crosses may be of theoretical interest only, the theoretical problems involved are of similar nature to those which would occur in designing machines for more practical purposes, such as those which have already been seriously proposed, namely: for the routing of telephone calls based on individual circumstances rather than by fixed patterns; for the performance of symbolic (non-numerical) mathematical operations ; for translating from one language to another; for making strategic decisions in simplified military operations ; and for the orchestration of a melody. Machines of this type are, as Dr. Shannon points out, an extension over the ordinary use of numerical computers in several ways, for the entities dealt with represent not numbers but chess positions, mathematical expressions, words, etc. Something of the nature of judgment is involved, and the solutions are not merely right or wrong but choose some form of quality between the best and worst solution.

Chess-playing machines are not new, and Dr. Shannon refers briefly to the considerable literature on the subject. $\mathrm{He}_{\Theta}$ mentions the Maezel chess automaton invented by von Kempelen, which was undoubtedly operated by a concealed chess master. The chess-playing machine made in 1914 by Torrès $y$ Quévedo ${ }^{2}$, the director of the Laboratorio de Automática in Madrid, was an honest attempt and could play an end-game of king and rook against king. This involves a comparatively simple problem, since in this particular end-game any one of the opponent's moves can be countered by the machine by one of five basic moves. 